\title{
Solubilization of polysaccharides and functional components of ginger (Zingiber officinale Rosc.) using ethanol and enzyme
}

\author{
Dong-Geon Nam, Mina Kim, Pereum Im, Jeong-Sook Choe, Ae-Jin Choi* \\ Functional Food \& Nutrition Division, National Institute of Agricultural Science (NIAS), \\ Rural Development Administration (RDA), Wanju 55365, Korea
}

\section{주정과 효소 복합 처리를 활용한 생강의 다당류 및 기능성분 수용화}

\author{
남동건·김민아·임푸름·최정숙·최애진* \\ 농촌진흥청 국립농업과학원 농식품자원부 기능성식품과
}

\begin{abstract}
The objectives of this study were to increase the contents of functional ingredients and water soluble polysaccharides obtained from ginger extracts using ethanol and enzymes and to determine the applicability in pilot-scale production for the food industry. The processing of ethanol-treated extract (step I) depended on the extraction methods and time period of extraction. The enzyme-treated extract (step II) was processed with or without pH adjustment. The water soluble index (WSI) and total polyphenol (TP) content of the enzyme-treated extract (B) without pH adjustment decreased by $5.1 \%$ and $0.85 \%$, respectively, as compared with that of the pH-adjusted extract $(\mathrm{A})$. For the ethanol-treated extract processed by the reflux method, WSI of $9.59 \%$, TP content of $4.75 \%$, total flavonoid (TF) content of $1.38 \%$, and total gingerol/shogaol content of $6.50 \%$ were obtained. The total gingerol/shogaol content was higher by 3.6 times than those obtained from the extract processed by the stiming method. As the reflux extraction time increased, WSI and the TP, TF, total gingerol/shogaol contents increased significantly. Therefore, the optimum condition for processing the ethanol extract involved refluxing for $2 \mathrm{~h}$ at $83^{\circ} \mathrm{C}$ unadjusting the optimum pH. The variability of analysis of the parameters depending on different extraction scales was confirmed to be within $\pm 7 \%$. The ethanol and enzyme based approach described in this study would be beneficial to food industries for developing functional products and materials from ginger.
\end{abstract}

Key words : ginger (Zingiber officinale Rosc.), ethanol, enzyme, solubilization, functional components

\section{서 론}

생강(Zingiber officinale Roscoe)은 Zingiberaceae종에 속 하는 자엽 식물의 뿌리 작물로 특유의 향과 맛을 가지고 있어 세계적으로 재배되고 이용되는 향신료 중 하나이다 (1). 생강 성분은 탄수화물, 단백질, 지질 및 기타 화합물의 복합체로 세포벽의 구조는 일반적인 구근류에 속하는 뿌리

*Corresponding author. E-mail : aejini77@korea.kr Phone : 82-63-238-3691; Fax : 82-63-238-3843

Received 20 May 2019; Revised 01 July 2019; Accepted 12 July 2019.

Copyright (C) The Korean Society of Food Preservation. All rights reserved.
작물과 유사한 형태이고, 셀룰로스와 구조 단백질을 포함 하는 전분질이 엉켜있는 복잡한 형태이다. 생강의 향미성 분으로는 a-zingiberene, $\beta$-sesquiphellandrene, $\beta$-bisbolene 등이 있으며(2), 정유 성분으로는 주로 유리형으로 존재하 는 휘발성 오일인 monoterpenoid와 sesquiterpene ( $\beta$ -sesquiphellandrene, $\beta$-bisbolene 등) 탄화수소로 구성되어 있고, 비휘발성 페놀류인 oleoresin은 gingerols와 shogaols 및 zingerone (a-zingiberene)으로 구성되어 있다(3). 특히, oleoregin성분에 함유된 gingerols와 shogaols 은 항산화, 항 염증, 혈류 개선, 콜레스테롤 저하 등의 기능성이 알려져 있다.

생강에 대한 국내외 연구는 생강 저장 기간 연장(4), 저장 성 향상 및 관리 $(5,6)$ 등 이 있으며, 생강 유용성분의 손실을 
최소화하는 건조 방법 연구 $(7,8)$ 가 있다. 국내에서 생강은 김치, 젓갈 등의 향신료, 한과, 음료 및 다(茶류 등 제한적으 로 사용되고 있다(9). 반면 유럽 및 미국에서는 생강을 염장, 당장, 건조 분말 형태로 가공하여 주로 디저트류에 활용되 었다가 기능적 성분의 효능이 입증되면서 건강기능성 소재 로 각광받고 있으며, 식품첨가물, 소스류, 유기농 주스, 시 럽류, 잼류, 스프레드류 등으로 다양하게 상품화되고 있다. 이 외에도 생강은 정유성분과 oleoregin성분에서 기인하는 탈취, 항균 효과가 있어 화장품 및 살균제 등으로도 사용되 고 있다.

국내에서 생강 사용이 제한적인 원인으로는 생강 작물 특성상 저온 장애 및 저장 중 진균으로 인한 생체 유통 문제, 기계적인 탈피 과정 중 불규칙한 생강의 표면 손상에 의한 진균 등의 오염 노출 문제가 있으며(10), 잔존하는 전분에 의한 여과 공정에서의 낮은 추출 수율 문제 등이 있다. 이와 같은 생강의 원료 특성 및 가공 상의 문제점들을 해결하기 위해 초음파, 마이크로파, 초임계, 고압 등 여러 접근법이 시도되어 추출 효율 증대에 대한 연구가 다수 진행되었으나 농가 단위의 영농조합이나 중소 규모의 생산 시설에서는 이를 적용하기에 실질적인 어려움이 많다. 또 한, 기기설비 구축에 따른 초기 투자비용이 많이 소요되고, 복잡한 추출 공정으로 인한 전문 인력 및 다수의 생산 인력 을 필요로 하게 된다. 일반적인 식품 생산에 많이 적용하고 있는 효소처리 수용화 기술은 단백질과 펙틴, 섬유소, 전분 등의 다당류 성분의 분해를 용이하게 하며, 이로 인한 추출 수율 및 기능성분의 추출 증진 효과를 가져 올 수 있다. 또한, 효소처리 전 단계에서 주정 추출을 하게 되면 저분자 물질의 기능성분을 다량으로 용출시킬 수 있으며, 기능성 분 품질 표준화를 위한 고농도 농축액으로도 사용이 가능하 다.

따라서, 본 연구에서는 생강의 다당류 수용화 효율을 증 진시키기 위한 효소처리 조건과 기능성분의 추출 수율을 극대화할 수 있는 주정처리 최적 조건을 탐색하고자 하였 다. 또한 추출 용량별로 각 성분의 함량 비교를 통하여 대량 생산의 적용성을 검토하고자 하였다.

\section{재료 및 방법}

\section{재료 및 시약}

생 생강(Zingiber officinale Rosc.)은 전라북도 완주 봉동 지역에서 2017년 10월에 생산된 것을 구입하여 사용하였으 며, 탈피 및 세척 과정을 거쳐 슬라이스한 생강은 동결건조 후 분쇄하여 $-20^{\circ} \mathrm{C}$ 에 보관하면서 실험에 사용하였다. 생강 주정 추출에 사용된 발효주정은 Ethanol Supplies World Co.(Jeonju, Korea)에서 구입하여 사용하였고, pectinex Ultra SP-L( $\geq 3,800 \mathrm{PGNU} / \mathrm{mL})$, termamyl $120 \mathrm{~L}(120 \mathrm{KNU} / \mathrm{g})$
은 Novozymes(Novo Nordisk, Copenhagen, Denmark)의 제 품을 구입하여 사용하였다. 분석 시약으로 dinitrosalicylic acid(DNS), folin-ciocalteu's reagent, gallic acid, glucose 및 catechin은 Sigma-Aldrich Co.(St. Louis, MO, USA)에서, 지 표성분 표준물질 6-gingerol, 8-gingerol, 10-gingerol, 6-shogaol, 8-shogaol, 10-shogaol은 Chromadex(Laguna Hills, CA, USA)에서 구입하여 사용하였다.

\section{생강 효소처리 방법 선정}

생강의 효소처리는 선행 연구된 Nam 등(11)의 고압 효소 처리를 변형하여 대량 생산 및 현장 적용성이 증진된 단일 효소처리 방법으로 진행하였다. 식물 세포벽 분해 효소는 Pectinex Ultra SP-L(Novozymes, Novo Nordisk, Copenhagen, Denmark)을 사용하였으며, 전분 분해 효소는 Termamyl 120L(Novozymes, Novo Nordisk, Copenhagen, Denmark)을 사용하였다. 단일효소처리구 $\mathrm{A}$ 는 생강 분말 $5 \mathrm{~g}$ 에 20배에 해당하는 증류수 $100 \mathrm{~mL}$ 을 가하여 혼합한 후, $0.1 \mathrm{~N}$ 수산화나트륨 용액과 $0.1 \mathrm{~N}$ 염산 용액으로 세포벽 분해효소의 최적 $\mathrm{pH}$ 인 4.0 으로 조정하였다. 세포벽 분해 효소는 생강 분말의 $1 \%(\mathrm{w} / \mathrm{w})$ 농도로 첨가한 후 투명 파우 치 $\left(\mathrm{PE}\right.$ 재질)에 넣고 탈기 및 밀봉하여 상압의 $50^{\circ} \mathrm{C}$ 항온수 조(WiseBath, MaXturdy, Daihan sci., Wonju, Korea)에서 $100 \mathrm{rpm}$ 속도로 2시간 동안 처리하였다. 전분 분해효소 처리를 위하여 상온으로 식힌 다음 $\mathrm{pH} 6.0$ 으로 조정하였다. 전분 분해 효소도 생강 분말의 $1 \%(\mathrm{w} / \mathrm{w})$ 농도로 첨가한 후 $93^{\circ} \mathrm{C}$ 의 항온수조에서 1 시간 동안 처리한 다음, 효소 불활성 화를 위하여 $100^{\circ} \mathrm{C}$ 에서 5 분간 처리하였다. 이 때, 대량 생산 에서 $\mathrm{pH}$ 조정의 단위 공정 축소 가능성을 평가하고자 단일 효소처리구 $\mathrm{B}$ 는 모든 과정을 처리구 $\mathrm{A}$ 와 동일하게 진행하 면서 효소의 최적 $\mathrm{pH}$ 조정 과정만 생략하고 진행하였다. 대조구 $(\mathrm{CON})$ 로는 냉각환류추출장치를 이용하여 $100^{\circ} \mathrm{C}$ 에 서 2시간 가열처리만 하여 비교하였다.

\section{생강 주정처리 방법 선정}

주정 처리의 최적 조건을 선정하기 위한 방법은 교반법 (Stirring, 2시간, $25^{\circ} \mathrm{C}$ ), 초음파법(Sonication, 0.5 시간, $25^{\circ} \mathrm{C}$ ), 환류냉각법 (Reflux, 2 시간, $83^{\circ} \mathrm{C}$ )으로 비교하였다. 주정처리 후 효소처리를 실시하였으며 추출 단계별로 수용 화 특성과 기능성분 변화를 비교하였다. 주정처리 시간은 최적의 방법으로 선정된 환류냉각법을 이용하여 $0.5,1,2$ 시 간으로 진행하였다.

\section{생강 처리 용량별 비교}

위의 실험에서 최적의 주정 및 효소처리 방법으로 선정 된 환류냉각법 $\left(2\right.$ 시간, $83^{\circ} \mathrm{C}$ )과 $\mathrm{pH}$ 미조정 효소처리법(단일 효소처리구 B)을 이용하여, 추출 단계별로 소용량 $(0.1,1$ $\mathrm{L})$ 과 대용량 $(35 \mathrm{~L})$ 규모에서 비교하였다. 소용량의 주정처 
리(Step I)는 동결건조 생강 분말 각각 $5,50 \mathrm{~g}$ 을 이용하였으 며, 고형분 대비 20 배에 해당하는 발효주정을 첨가하여 추 출하였다. 추출 및 여과 후에 남은 생강 고형물을 드라이오 븐(OF-22GW, JEIO-TECH, Daejeon, Korea) $50^{\circ} \mathrm{C}$ 에서 24시 간 건조하여 다음 단계인 효소처리(Step II)를 진행하였다.

대용량 추출은 $50 \mathrm{~L}$ 반응조(F-50, Kobiotech, Incheon, Korea)를 이용하여 Fig. 1과 같이 진행하였다. 주정처리 (Step I)는 동결건조 생강 분말 $1,750 \mathrm{~g}$ 에 발효주정(고형분 대비 20배)을 가하여 혼합한 다음 $83^{\circ} \mathrm{C}$ 에서 $200 \mathrm{rpm}$ 교반속도로 4 시간 동안 추출하였다. 처리된 생강 주정 추출액은 $40^{\circ} \mathrm{C}$ 이하로 냉각 후, 추출포 $(\mathrm{PP}$ 부직포 재질, $60 \times 70 \mathrm{~cm}, 2$ 장)로 1차 압착여과한 다음, 마이크로 필터 (SARTOCLEAN GF $3+0.8 \mu \mathrm{m}$, Sartorius, AugustSpindler-Strasse, Goettingen, Germany)를 사용하여 압력 1.2 $\mathrm{kg} / \mathrm{cm}^{2}$ 이하에서 2 차 여과하였다. 여과액은 주정처리 시료 로 사용하였으며, 추출박은 열풍건조기(DO-100, HS Tech, Seongnam, Korea)에서 $50^{\circ} \mathrm{C}, 24$ 시간 건조하여 효소처리 단계에서 사용하였다. 효소처리 단계(Step II)는 건조된 생 강 추출박을 넣고 20 배에 해당하는 물을 가하여 단일효소 처리 $\mathrm{B}$ 의 방법과 동일한 방법으로 진행하였다. 첨가된 효소 의 불활성을 위해 $100^{\circ} \mathrm{C}$ 에서 5 분간 처리 후, $50^{\circ} \mathrm{C}$ 이하로 냉각하였으며, 여과는 주정처리 단계와 동일한 방법으로 진행하였다.

\section{생강 추출물의 수용화 특성}

수분용해지수(Water solubility index, WSI)와 수분흡착 지수(Water absorption index, WAI)는 Anderson RA 등(12) 의 방법을 응용하여 이용하였으며, 산출식은 아래와 같다. 총 당(Total sugar, TS)은 Phenol- $\mathrm{H}_{2} \mathrm{SO}_{4}$ 법(13)을 이용하였 고, 환원당(Reducing sugar, RS)은 DNS 방법(14)으로 550 $\mathrm{nm}$ 에서 흡광도를 측정하여 포도당 함량에 상당하는 값 (glucose equivalent, GE, g\%)으로 나타내었다.

$$
\begin{aligned}
\text { WSI }(\%)= & {[(\text { soluble solids } \mathrm{g} / 5 \mathrm{~mL}) \times \text { supernatant total Vol. }} \\
& (\mathrm{mL})] / 5 \mathrm{~g} \times 100
\end{aligned}
$$

$\mathrm{WAI}(\mathrm{g} / \mathrm{mL})=$ weight of precipitate/weight of dry solids

\section{생강 추출물의 기능성분}

총 폴리페놀(Total polyphenol, TP) 함량은 Folin-Denis법 (15)을 변형하여 측정하였으며, 표준 물질로 gallic acid를 이용하였다. 총 플라보노이드(Total flavonoid, TF) 함량은 Zhishen 등(16)의 방법을 변형하여 측정하였으며, 표준 물 질로는 (+)-Catechin을 이용하였다. 생강의 지표성분인 6-gingerol(6-G), 8-gingerol(8-G), 10-gingerol(10-G), 6-shogaol (6-S), 8-shogaol(8-S), 10-shogaol(10-S)은 HPLC(Nexera X2, Shimadzu, Kyoto, Japan)를 이용하여 분석하였다. 생강 주정 처리 추출액을 $0.2 \mu \mathrm{m}$ syringe filter(Millipore, Billetica, MA, USA)로 여과한 것을 분석 시료로 하였고, 효소처리 추출액 은 동결 건조한 후 $2 \mathrm{~mL}$ 의 메탄올에 용해시킨 후 주정 처리 추출액과 동일한 방법으로 여과하여 분석하였다. 분 석 주입량은 $2 \mu \mathrm{L}$ 로 사용하였다. 이 때 각 성분들의 표준 곡선은 최종 농도가 $10,50,100,500,1,000 \mathrm{ppm}$ 이 되도록 하여 $280 \mathrm{~nm}$ 에서 측정하였다. 분석 조건은 Table 1 과 같다.

\section{통계분석}

실험 결과는 3회 반복하여 측정한 값을 SPSS(Version 18.0, Chicago, IL, USA)를 이용하여 평균치와 표준편차로 나타내었다. ANOVA test를 실시하여 유의성이 있는 경우 에는 Duncan의 다중범위검정(유의수준 $5 \%$ )을 이용하였다.
Step I : Ethanol extraction

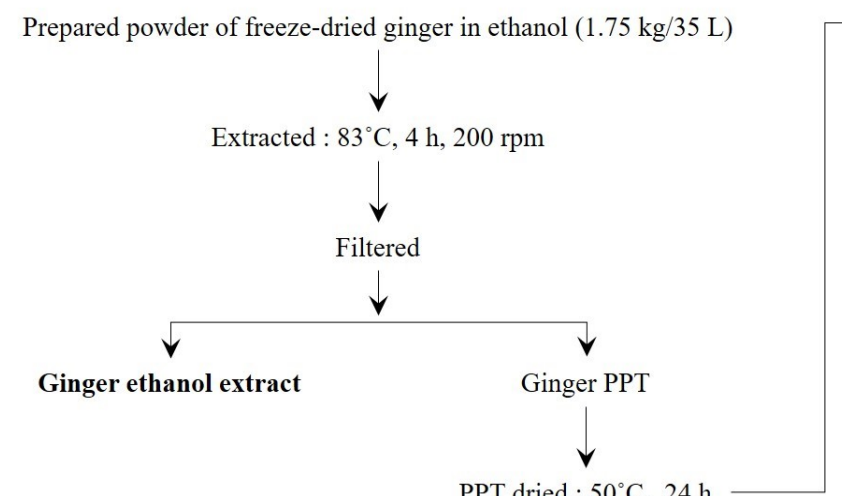

Step II : Enzyme extraction

Added water in dried ginger PPT

Added enzymes for cell wall degradation (Pectinex Ultra SP-L, $1 \%$, w/w) $: 50^{\circ} \mathrm{C}, 2 \mathrm{~h}, 200 \mathrm{rpm}$

Added enzymes for starch degradation (Termamyl 120L, $1 \%$, w/w) : $93^{\circ} \mathrm{C}, 1 \mathrm{~h}, 200 \mathrm{rpm}$

Inactivated enzyme : $100^{\circ} \mathrm{C}, 5 \mathrm{~min}, 200 \mathrm{rpm}$

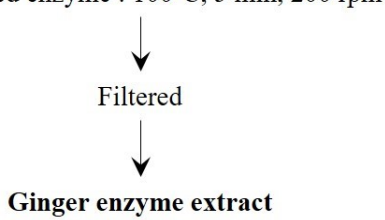

Fig. 1. Scheme for extraction processing from ginger by ethanol and enzyme treatme. 


\section{결과 및 고찰}

효소처리 방법별 생강의 수용화 특성 변화

최적 $\mathrm{pH}$ 조정 유무에 따른 효소처리 방법별 생강의 수용 화 특성을 비교한 결과는 Table 2 와 같다. 단일효소처리구 $\mathrm{A}$ 와 $\mathrm{B}$ 의 $\mathrm{WSI}$ 는 각각 $58.56 \%, 53.44 \%$ 로 대조구 $(\mathrm{CON})$ $15.35 \%$ 에 비하여 3.5-3.8배 정도 유의적으로 높게 나타났으 며 $(\mathrm{p}<0.001)$, 단일효소처리구 $\mathrm{B}$ 는 $\mathrm{A}$ 에 비하여 $5.1 \%$ 정도 낮게 나타났다. $\mathrm{TS}$ 는 $\mathrm{CON}$ 에 비하여 단일효소처리구 $\mathrm{A}$ 와 $\mathrm{B}$ 가 유의적으로 높게 나타났으며 $(\mathrm{p}<0.001), \mathrm{A}$ 와 $\mathrm{B}$ 간에

Table 1. Operating condition of HPLC for 6, 8, 10 gingerol and shogaol

\begin{tabular}{|c|c|c|c|}
\hline Parameters & \multicolumn{3}{|c|}{ Operating condition } \\
\hline HPLC system & \multicolumn{3}{|c|}{ Nexera X2 SHIMADZU, UPLC } \\
\hline Detector & \multicolumn{3}{|c|}{ DAD, UV, $280 \mathrm{~nm}$} \\
\hline Column & \multicolumn{3}{|c|}{ Kinetex XB.C18 $100 \AA(1.7 \mu \mathrm{m}, 150 \times 2.1 \mathrm{~mm})$} \\
\hline Mobile phase & \multicolumn{3}{|c|}{$\begin{array}{l}\text { A: } 0.1 \% \text { acetic acid in water }(\mathrm{V} / \mathrm{V}, \%) \\
\text { B: } 0.1 \% \text { acetic acid in acetonitrile }(\mathrm{V} / \mathrm{V}, \%)\end{array}$} \\
\hline \multirow{16}{*}{ Gradient elution } & Time (min) & $\mathrm{A}(\%)$ & $\mathrm{B}(\%)$ \\
\hline & 0.5 & 90 & 10 \\
\hline & 2.5 & 60 & 40 \\
\hline & 4.5 & 45 & 55 \\
\hline & 6.0 & 40 & 60 \\
\hline & 8.0 & 35 & 65 \\
\hline & 9.5 & 35 & 65 \\
\hline & 11.5 & 35 & 65 \\
\hline & 13.0 & 30 & 70 \\
\hline & 14.5 & 25 & 75 \\
\hline & 16.0 & 20 & 80 \\
\hline & 17.5 & 15 & 85 \\
\hline & 20.0 & 10 & 90 \\
\hline & 25.0 & 10 & 90 \\
\hline & 26.0 & 90 & 10 \\
\hline & 29.0 & 90 & 10 \\
\hline Injection volume $(\mu \mathrm{L})$ & \multicolumn{3}{|c|}{2} \\
\hline Flow rate $(\mathrm{mL} / \mathrm{min})$ & \multicolumn{3}{|c|}{0.3} \\
\hline Column temp. $\left({ }^{\circ} \mathrm{C}\right)$ & \multicolumn{3}{|c|}{30} \\
\hline
\end{tabular}

유의적인 차이는 없었다. RS도 $\mathrm{TS}$ 와 유사한 경향을 나타내 었으며, 단일효소처리구 $\mathrm{B}$ 는 $\mathrm{A}$ 에 비하여 $2.5 \%$ 낮게 나타났 다. 일반적으로 원료를 가수분해하는 과정에 있어 효소는 $\mathrm{pH}$ 의 농도에 따라 크게 영향을 받으며, 효소에 해당되는 일정한 $\mathrm{pH}$ 의 범위에 속할 때 최적 활성을 나타낸다. 본 연구에 사용된 효소 pectinex Ultra SP-L는 Aspergillus aculeatus에서 분리된 polygalacturonase로 식물 세포벽 분 해를 위해 식품업체에서 가장 많이 사용하고 있으며, $50^{\circ} \mathrm{C}$, $\mathrm{pH}$ 4.0-4.5의 범위에서 최적의 활성을 나타낸다(17). Termamyl 120L은 Bacillus licheniformis에서 분리된 a -amylase로 $90-100^{\circ} \mathrm{C}$ 정도의 고온에 안정하며 $93^{\circ} \mathrm{C}, \mathrm{pH}$ 6.0 에서 최적의 활성을 나타낸다(18). Pectinex 처리 전 생강 분산액의 $\mathrm{pH}$ 는 5.5-6.0 정도이며, termamyl $120 \mathrm{~L}$ 처리 전 생강 추출액의 $\mathrm{pH}$ 는 5.0-5.5 정도로 효소 활성을 위한 최적 의 $\mathrm{pH}$ 범위에서 크게 벗어나지 않았다. 결과적으로 효소처 리를 위한 $\mathrm{pH}$ 조정 단계는 생강의 세포벽 및 전분을 분해를 촉진할 수는 있지만, 대량 추출을 위한 생산 시간 및 비용 등을 고려하면 불필요한 과정일 수 있다고 판단되었다.

\section{효소처리 방법별 생강의 기능성분 변화}

$\mathrm{pH}$ 조정 유무에 따른 생강 추출물의 기능성분 변화를 비교한 결과는 Table 3 과 같다. $\mathrm{TP}$ 는 A $2.37 \%, \mathrm{~B} 1.52 \%$, $\mathrm{CON} 1.43 \%$ 로 처리 방법에 따라 유의적 차이가 나타났다 $(\mathrm{p}<0.001) . \mathrm{B}$ 는 $\mathrm{A}$ 에 비해 $0.9 \%$ 감소하였다. $\mathrm{TF}$ 는 $0.33-0.68 \%$ 의 범위로 처리 방법별 유의차가 있었으며 ( $\mathrm{p}<0.001), \mathrm{TP}$ 의 경향과 유사하였다. $\mathrm{B}$ 는 $\mathrm{A}$ 에 비해 $0.3 \%$ 낮게 나타났다. 지표성분인 6-G, 8-G, 10-G, 6-S, 8-S, 10-S의 함량을 합산하여 비교한 결과 A $1.53 \%, \mathrm{~B} 1.08 \%, \mathrm{CON}$ $0.57 \%$ 로 처리 방법별 유의적 차이가 나타났다 $(\mathrm{p}<0.001)$. $\mathrm{B}$ 는 $\mathrm{A}$ 에 비해 $0.5 \%$ 낮게 나타났으나 $\mathrm{CON}$ 대비 1.9 배 증가 되었다. $\mathrm{pH}$ 조정 유무에 따라 기능성분이 0.3-0.9\% 정도 감소되는 결과가 나타났으나, 수용화 변화 특성의 결과에 서와 마찬가지로 대량 추출에서는 $\mathrm{pH}$ 조정 단계를 생략하 고 진행하는 것이 더 바람직하다고 판단되었다.

Table 2. Water solubility of ginger extracts as affected by $\mathrm{pH}$ adjustment

\begin{tabular}{ccccc}
\hline Treatment & ${ }^{2}$ WSI $(\%)$ & WAI $(\mathrm{g} / \mathrm{mL})$ & TS $(\%)$ & RS $(\%)$ \\
\hline${ }^{1)}$ CON & $\left.{ }^{3}\right) 15.35 \pm 0.10^{(4)}$ & $1.35 \pm 0.04^{\mathrm{b}}$ & $0.24 \pm 0.03^{\mathrm{b}}$ & $0.14 \pm 0.02^{\mathrm{c}}$ \\
A & $58.56 \pm 2.24^{\mathrm{a}}$ & $1.86 \pm 0.10^{\mathrm{b}}$ & $30.99 \pm 0.16^{\mathrm{a}}$ & $21.23 \pm 0.01^{\mathrm{a}}$ \\
B & $53.44 \pm 0.64^{\mathrm{b}}$ & $5.53 \pm 0.51^{\mathrm{a}}$ & $30.81 \pm 0.67^{\mathrm{a}}$ & $18.75 \pm 0.21^{\mathrm{b}}$ \\
\hline F-value & $921.55^{* * 5)}$ & $173.44^{* * *}$ & $5954.82^{* * *}$ & $28,100.43^{* * *}$ \\
\hline
\end{tabular}

\footnotetext{
${ }^{1)} \mathrm{CON}, 100^{\circ} \mathrm{C}$ reflux for $2 \mathrm{~h}$; A, water bath shaking (adjusted $\mathrm{pH}$ ); B, water bath shaking (unadjusteded $\mathrm{pH}$ ).

2)WSI, water solubility index; WAI, water absorption index; TS, total sugar; RS, reducing sugar.

${ }^{3)}$ All values are mean $\pm \mathrm{SD}(\mathrm{n}=3)$.

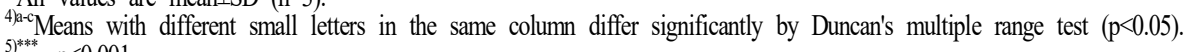

5), $\mathrm{p}<0.001$.
} 
Table 3. Functional component content of ginger extracts as affected by $\mathrm{pH}$ adjustment

\begin{tabular}{|c|c|c|c|c|c|c|c|c|c|}
\hline Treatment & ${ }^{2)} \mathrm{TP}(\%)$ & TF $(\%)$ & Total (\%) & 6-G (\%) & 8-G (\%) & $10-\mathrm{G}(\%)$ & 6-S (\%) & 8-S (\%) & $10-\mathrm{S}(\%)$ \\
\hline${ }^{1)} \mathrm{CON}$ & ${ }^{3)} 1.43 \pm 0.02^{(4)}$ & $0.33 \pm 0.02^{\mathrm{c}}$ & $0.57 \pm 0.06^{\mathrm{c}}$ & $0.45 \pm 0.05^{\mathrm{c}}$ & $0.03 \pm 0.00^{b}$ & $0.00 \pm 0.00^{c}$ & $0.05 \pm 0.00^{b}$ & $0.04 \pm 0.01$ & $0.01 \pm 0.00$ \\
\hline A & $2.37 \pm 0.05^{\mathrm{a}}$ & $0.68 \pm 0.00^{\mathrm{a}}$ & $1.53 \pm 0.05^{\mathrm{a}}$ & $1.22 \pm 0.03^{\mathrm{a}}$ & $0.09 \pm 0.00^{\mathrm{a}}$ & $0.03 \pm 0.01^{b}$ & $0.06 \pm 0.00^{\mathrm{ab}}$ & $0.11 \pm 0.00$ & $0.02 \pm 0.00$ \\
\hline B & $1.52 \pm 0.01^{\mathrm{b}}$ & $0.37 \pm 0.01^{\mathrm{b}}$ & $1.08 \pm 0.13^{\mathrm{b}}$ & $0.78 \pm 0.09^{b}$ & $0.10 \pm 0.02^{\mathrm{a}}$ & $0.06 \pm 0.01^{\mathrm{a}}$ & $0.08 \pm 0.01^{\mathrm{a}}$ & $0.05 \pm 0.01$ & $0.02 \pm 0.00$ \\
\hline F-value & $890.94^{* * * 5)}$ & $911.55^{* * *}$ & $84.34^{* * * *}$ & $117.07^{* * *}$ & $28.79^{* *}$ & $42.00^{* * *}$ & $7.63^{*}$ & NS & NS \\
\hline
\end{tabular}

${ }^{1)}$ Abbreviations are the same as in Table 2.

${ }^{2}$ TP, total polyphenol; TF, total flavonoids; Total, sum of the 6, 8, 10 gingerol and 6, 8, 10 shogaol; 6-G, 6-gingerol; 8-G, 8-gingerol; 10-G, 10-gingerol; 6-S, 6-shogaol; 8-S, 8-shogaol; 10-S, 10-shogaol.

${ }^{3)}$ All values are mean \pm SD $(n=3)$.

${ }_{5)^{*}}$ a-c Means with different small letters in the same column differ significantly by Duncan's multiple range test $(\mathrm{p}<0.05)$.

)$^{*}, \mathrm{p}<0.05 ;{ }^{* *}, \mathrm{p}<0.01 ;{ }^{* * *}, \mathrm{p}<0.001$; NS, not significant.

\section{주정처리 방법별 생강의 수용화 특성 변화}

주정처리 방법별 생강의 수용화 특성에 미치는 영향을 살펴본 결과는 Table 4 와 같다. 주정처리 단계인 Step I의 $\mathrm{WSI}$ 는 환류냉각법이 $9.59 \%$, 초음파법이 $8.23 \%$, 교반법이 $5.82 \%$ 로 환류냉각법이 유의적으로 높게 나타났다( $<<0.001)$. $\mathrm{Kim}$ 과 Youn(19)의 참취 에탄올 추출액 연구에서도 추출 수율 비교시 냉각환류추출 $31.80 \%$, 초음파추출 $31.19 \%$, 가압가열추출 $28.38 \%$, 교반추출 $28.33 \%$, 저온고압추출 $21.38 \%$ 로 환류냉각추출이 유의적으로 높았다고 보고하였 다. 또한, Kim과 Lee(20)의 용매 추출 방법을 달리한 달맞이 꽃 연구에서 추출 수율은 환류냉각추출 $46.33 \%$, 초음파추 출 $44.75 \%$, 교반추출 $40.23 \%$ 로 환류냉각추출이 유의적으 로 높았다고 보고하였다. Step I의 TS는 환류냉각법이
$3.48 \%$ 로 초음파법 $0.46 \%$ 와 교반법에 비하여 유의적으로 높게 나타났다 $(\mathrm{p}<0.001) . \mathrm{RS}$ 역시 환류냉각법이 $1.27 \%$ 로 초음파법과 교반법에 비하여 1.5-1.9배 정도 유의적으로 높게 나타났다 $(\mathrm{p}<0.001)$.

효소처리 단계인 Step II의 WSI는 환류냉각법이 $49.21 \%$, 교반법이 $48.08 \%$, 초음파법이 $40.95 \%$ 로 환류냉각법과 교 반법이 유의적으로 높게 나타났다(p<0.01). WAI는 환류냉 각법이 $4.38 \mathrm{~g} / \mathrm{mL}$ 로 유의적으로 낮게 나타났으며 $(\mathrm{p}<0.01)$, 이러한 결과로 환류냉각법이 생강의 다당류의 수용화 및 분해에 더 효과적임을 확인할 수 있었다. 수분흡착지수인 $\mathrm{WAI}$ 가 높다는 것은 수분을 흡착할 수 있는 펙틴, 섬유소 등의 다당류가 분해되지 않고 남아 있다는 것을 의미하며, 수분용해지수인 WSI와 역의 상관성을 가지고 있다. TS와

Table 4. Water solubility content of ginger extracts as affected by treatment type and time

\begin{tabular}{|c|c|c|c|c|c|c|}
\hline & & Time (h) & ${ }^{2)}$ WSI (\%) & WAI $(\mathrm{g} / \mathrm{mL})$ & TS (\%) & RS (\%) \\
\hline \multirow{7}{*}{${ }^{1)}$ Step I } & Stirring & 2 & 4) $5.81 \pm 0.29$ & - & $\mathrm{b}_{0.37 \pm 0.06}$ & ${ }^{\mathrm{c}} 0.67 \pm 0.01$ \\
\hline & Sonication & 0.5 & b $8.23 \pm 0.84$ & - & b $0.46 \pm 0.16$ & ${ }^{b} 0.86 \pm 0.01$ \\
\hline & Reflux & 2 & ${ }^{\mathrm{a}} 9.59 \pm 0.17^{\mathrm{A}}$ & - & a $3.48 \pm 0.08^{\mathrm{A}}$ & ${ }^{\mathrm{a}} 1.27 \pm 0.01$ \\
\hline & \multicolumn{2}{|c|}{ F-value } & $40.32^{* * * 6)}$ & - & $831.84^{* * *}$ & $995.79^{* * *}$ \\
\hline & \multirow{2}{*}{ Reflux } & 1 & $7.95 \pm 0.21^{\mathrm{B}}$ & - & $3.05 \pm 0.16^{\mathrm{B}}$ & $1.26 \pm 0.05$ \\
\hline & & 0.5 & 3) $7.39 \pm 0.28^{(5)}$ & - & $3.28 \pm 0.07^{\mathrm{A}}$ & $1.20 \pm 0.04$ \\
\hline & \multicolumn{2}{|c|}{ F-value } & $79.19^{* * *}$ & - & $11.29^{* *}$ & NS \\
\hline \multirow{7}{*}{ Step II } & Stirring & 2 & a $48.08 \pm 0.91$ & a $7.10 \pm 0.95$ & a $29.53 \pm 0.69$ & ${ }^{b} 4.52 \pm 0.09$ \\
\hline & Sonication & 0.5 & ${ }^{b} 40.95 \pm 1.80$ & a $7.36 \pm 0.99$ & ${ }^{b} 25.08 \pm 0.71$ & ${ }^{c} 4.11 \pm 0.11$ \\
\hline & Reflux & 2 & ${ }^{\mathrm{a}} 49.21 \pm 3.45^{\mathrm{A}}$ & ${ }^{b} 4.38 \pm 1.10$ & ${ }^{\mathrm{a}} 29.85 \pm 0.07^{\mathrm{A}}$ & ${ }^{\mathrm{a}} 6.93 \pm 0.26^{\mathrm{A}}$ \\
\hline & \multicolumn{2}{|c|}{ F-value } & $11.33^{* *}$ & $14.17^{* *}$ & $64.68^{* * *}$ & $237.39^{* * *}$ \\
\hline & \multirow{2}{*}{ Reflux } & 1 & $45.30 \pm 0.91^{\mathrm{AB}}$ & $4.06 \pm 0.41$ & $28.98 \pm 0.16^{\mathrm{B}}$ & $2.10 \pm 0.08^{\mathrm{B}}$ \\
\hline & & 0.5 & $41.58 \pm 1.58^{\mathrm{B}}$ & $4.30 \pm 0.89$ & $25.74 \pm 0.48^{\mathrm{C}}$ & $1.21 \pm 0.03^{\mathrm{C}}$ \\
\hline & \multicolumn{2}{|c|}{ F-value } & $8.62^{*}$ & NS & $160.12^{* * *}$ & $1166.34^{* * *}$ \\
\hline
\end{tabular}

${ }^{1)}$ Step I, stirring treatment $\left(25^{\circ} \mathrm{C}, 2 \mathrm{~h}\right)$; sonication treatment $\left(25^{\circ} \mathrm{C}, 0.5 \mathrm{~h}\right)$; reflux treatment $\left(83^{\circ} \mathrm{C}, 0.5,1\right.$, and $\left.2 \mathrm{~h}\right)$; Step II, enzyme treatment (water bath shaking, non-adjusted $\mathrm{pH}$, water extraction, pectinex ultra SP-L $(1 \%$ enzyme on substrate $5 \mathrm{~g}), 50^{\circ} \mathrm{C}, 2 \mathrm{~h}$ and termamyl $120 \mathrm{~L}(1 \%$ enzyme on substrate $\left.5 \mathrm{~g}) 100^{\circ} \mathrm{C}, 1 \mathrm{~h}\right)$.

${ }^{2}$ WSI, water solubility index; WAI, water absorption index; TS, total sugar; RS, reducing sugar.

${ }^{3)}$ All values are mean \pm SD $(n=3)$.

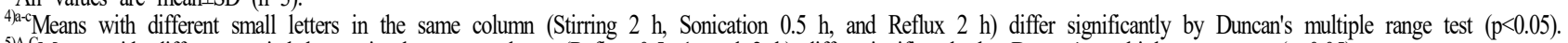

${ }^{5) A-C}$ Means with different capital letters in the same column (Reflux $0.5,1$, and $2 \mathrm{~h}$ ) differ significantly by Duncan's multiple range test ( $\mathrm{p}<0.05$ ).

${ }^{*}, \mathrm{p}<0.05 ;{ }^{* *}, \mathrm{p}<0.01 ;{ }^{* * *}, \mathrm{p}<0.001 ; \mathrm{NS}$, not significant. 
$\mathrm{RS}$ 역시 WSI와 마찬가지로 환류냉각법이 각각 $29.85 \%$, $6.93 \%$ 로 다른 추출법에 비하여 유의적으로 높게 나타났다 ( $\mathrm{p}<0.001)$. Won 등 $(21)$ 은 미나리 추출액의 에탄올 추출에 의한 변화에서 열수 및 $95 \%$ 에탄올을 이용하여 환류냉각으 로 추출한 미나리의 TS 함량은 각각 $15.97 \%, 5.35 \%$ 로 보고 하였다. 생강 역시 Step I의 주정처리 보다 물을 이용한 Step II의 효소처리에서 TS를 비롯한 WSI, RS가 높게 나타 난 것은 용매의 극성 차이에 의해 용출되는 물질 조성이 달라져 나타난 것으로 판단되었다.

환류냉각법의 처리 시간에 따른 Step I의 WSI는 2 시간 처리구가 $9.59 \%$ 로 1 시간(7.95\%)과 0.5 시간(7.39\%) 처리구 에 비하여 유의적( $\mathrm{p}<0.001)$ 으로 높게 나타났다. Kim 등(22) 은 사과 폴리페놀 추출 조건 최적화 연구에서 사과는 알코 올 추출 시 시료에 대한 처리 시간 보다 온도와 용매 조성의 영향이 더 크다고 보고하였다. 이는 원료의 품목에 따라 처리 시간, 온도, 용매 조성, 용매 비율 등이 추출 수율에 영향을 미칠 수 있음을 나타낸 것으로 생강의 주정추출에서 는 처리 시간과 온도가 크게 영향을 미치는 것을 확인할 수 있었다. Step I의 TS는 2 시간과 0.5 시간 처리구가 각각 $3.48 \%, 3.28 \%$ 로 1 시간 처리구 $3.05 \%)$ 에 비하여 유의적 $(\mathrm{p}<0.01)$ 으로 높게 나타났다. 또한, RS는 $1.20-1.27 \%$ 의 범위 로 시간에 따른 유의적인 차이는 나타나지 않았다.

처리 시간에 따른 Step II의 WSI는 2시간 처리구가
$49.21 \%$ 로 처리 시간이 증가할수록 유의적으로 높게 나타났 다 $(\mathrm{p}<0.05) . \mathrm{TS}$ 와 $\mathrm{RS}$ 함량 역시 2시간 처리구가 각각 $29.85 \%, 6.93 \%$ 로 처리 시간이 증가될수록 유의적으로 높게 나타났다 $(\mathrm{p}<0.001)$. 따라서, 생강의 수용화 특성 증진을 위 한 주정처리 최적 방법은 수분용해지수, 총당, 환원당이 유의적으로 가장 높게 나타난 환류냉각법 2 시간 처리로 확인되었다.

\section{주정처리 방법별 생강의 기능성분 변화}

주정처리 방법별 생강의 기능성분 변화를 살펴본 결과는 Table 5와 같다. 주정처리 단계인 Step I의 $\mathrm{TP}$ 는 환류냉각법 이 $4.75 \%$, 초음파법이 $3.62 \%$, 교반법이 $1.31 \%$ 순으로 나타 났으며, 환류냉각법이 교반법에 비해 3.6배 높게 나타났다. Jung 등(23)의 생강과 식물의 항산화 연구에서 건조 생강에 10 배의 $70 \%$ 에탄올을 첨가하여 실온에서 24 시간 동안 정치 추출한 추출액의 $\mathrm{TP}$ 함량은 $3.97 \%$ 로 보고하였다. 또한, 세포 내부 또는 세포벽에 결합되거나 분산되어 있는 식물 화합 물질은 용매 추출만으로는 추출하기 어려우며, 효소 처리 또는 화학·물리적인 처리 등에 의해 좀 더 효과적으로 추출할 수 있는 것으로 알려져 있다. TF는 환류냉각법이 $1.38 \%$ 으로 교반법과 초음파법에 비하여 2.2-2.3배 정도 유 의적으로 높게 나타났다 $(\mathrm{p}<0.001)$. 생강의 지표성분인 gingerol 및 shogaol의 총합과 6-gingerol(6-G)의 함량은 환

Table 5. Functional component content of ginger extracts as affected by treatment type and time

\begin{tabular}{|c|c|c|c|c|c|c|c|c|c|c|c|}
\hline & atment & Time (h) & ${ }^{2)} \mathrm{TP}(\%)$ & TF $(\%)$ & Total (\%) & 6-G (\%) & 8-G (\%) & $10-\mathrm{G}(\%)$ & 6-S (\%) & 8-S (\%) & 10-S (\%) \\
\hline \multirow{7}{*}{ 1)Step I } & Stirring & 2 & ${ }^{4) c} 1.31 \pm 0.03$ & ${ }^{b} 0.62 \pm 0.01$ & ${ }^{\mathrm{c}} 1.48 \pm 0.18$ & ${ }^{\circ} 0.84 \pm 0.07$ & ${ }^{\mathrm{c}} 0.15 \pm 0.01$ & ${ }^{\mathrm{c}} 0.39 \pm 0.10$ & ${ }^{b} 0.03 \pm 0.01$ & ${ }^{b} 0.02 \pm 0.02$ & ${ }^{b} 0.04 \pm 0.01$ \\
\hline & Sonication & 0.5 & ${ }^{b} 3.62 \pm 0.06$ & ${ }^{b} 0.60 \pm 0.05$ & $\mathrm{~b}_{3.57 \pm 1.09}$ & ${ }^{b} 2.05 \pm 0.58$ & b $0.40 \pm 0.16$ & ${ }^{b} 0.79 \pm 0.23$ & ${ }^{b} 0.04 \pm 0.00$ & a $0.22 \pm 0.08$ & ${ }^{b} 0.08 \pm 0.04$ \\
\hline & Reflux & 2 & ${ }^{\mathrm{a}} 4.75 \pm 0.07^{\mathrm{A}}$ & ${ }^{\mathrm{a}} 1.38 \pm 0.14^{\mathrm{A}}$ & ${ }^{\mathrm{a}} 6.50 \pm 0.20^{\mathrm{A}}$ & a $3.21 \pm 0.03$ & ${ }^{\mathrm{a}} 1.11 \pm 0.02^{\mathrm{A}}$ & ${ }^{\mathrm{a}} 1.36 \pm 0.23$ & ${ }^{\mathrm{a}} 0.23 \pm 0.01^{\mathrm{A}}$ & ${ }^{\mathrm{a}} 0.19 \pm 0.01^{\mathrm{A}}$ & ${ }^{\mathrm{a}} 0.39 \pm 0.02^{\mathrm{A}}$ \\
\hline & \multicolumn{2}{|c|}{ F-value } & $3,343.00^{* * * * 6}$ & $76.60^{* * *}$ & $45.21^{* * * *}$ & $37.32^{* * * *}$ & $83.09^{* * *}$ & $18.62^{* *}$ & $696.20^{* * *}$ & $15.37^{* *}$ & $151.12^{* * *}$ \\
\hline & \multirow{2}{*}{ Reflux } & 1 & $4.26 \pm 0.08^{\mathrm{B}}$ & $1.19 \pm 0.07^{\mathrm{AB}}$ & $5.92 \pm 0.29^{\mathrm{B}}$ & $3.09 \pm 0.07$ & $1.03 \pm 0.01^{\mathrm{B}}$ & $1.42 \pm 0.26$ & $0.16 \pm 0.01^{\mathrm{B}}$ & $0.08 \pm 0.03^{\mathrm{B}}$ & $0.14 \pm 0.02^{\mathrm{C}}$ \\
\hline & & 0.5 & ${ }^{3)} 4.08 \pm 0.13^{\mathrm{B} 5)}$ & $1.14 \pm 0.04^{\mathrm{B}}$ & $6.02 \pm 0.09^{\mathrm{B}}$ & $3.10 \pm 0.04$ & $0.99 \pm 0.02^{\mathrm{C}}$ & $1.43 \pm 0.02$ & $0.16 \pm 0.05^{\mathrm{B}}$ & $0.06 \pm 0.01^{\mathrm{B}}$ & $0.29 \pm 0.04^{\mathrm{B}}$ \\
\hline & \multicolumn{2}{|c|}{ F-value } & $39.45^{* * *}$ & $5.42^{*}$ & $6.36^{*}$ & NS & $55.63^{* * *}$ & NS & $5.33^{*}$ & $50.63^{* * *}$ & $61.58^{* * *}$ \\
\hline \multirow{7}{*}{ Step II } & Stirring & 2 & ${ }^{b} 0.94 \pm 0.01$ & ${ }^{\mathrm{a}} 0.14 \pm 0.01$ & ${ }^{\mathrm{a}} 0.07 \pm 0.00$ & ${ }^{\mathrm{a}} 0.07 \pm 0.00$ & - & - & - & - & - \\
\hline & Sonication & 0.5 & ${ }^{\mathrm{a}} 1.05 \pm 0.01$ & ${ }^{\mathrm{a}} 0.12 \pm 0.00$ & ${ }^{b} 0.04 \pm 0.00$ & ${ }^{\mathrm{b}} 0.04 \pm 0.00$ & - & - & - & - & - \\
\hline & Reflux & 2 & ${ }^{\mathrm{c}} 0.85 \pm 0.01$ & ${ }^{\mathrm{b}} 0.05 \pm 0.01^{\mathrm{B}}$ & ${ }^{c} 0.01 \pm 0.00$ & ${ }^{\mathrm{c}} 0.01 \pm 0.00$ & - & - & - & - & - \\
\hline & \multicolumn{2}{|c|}{ F-value } & $222.64^{* * *}$ & $50.25^{* * *}$ & $217.00^{* * *}$ & $217.00^{* * *}$ & - & - & - & - & - \\
\hline & \multirow{2}{*}{ Reflux } & 1 & $0.83 \pm 0.02$ & $0.10 \pm 0.01^{\mathrm{A}}$ & $0.01 \pm 0.00$ & $0.01 \pm 0.00$ & - & - & - & - & - \\
\hline & & 0.5 & $0.83 \pm 0.01$ & $0.10 \pm 0.02^{\mathrm{A}}$ & $0.00 \pm 0.00$ & $0.00 \pm 0.00$ & - & - & - & - & - \\
\hline & \multicolumn{2}{|c|}{ F-value } & NS & $7.37^{*}$ & NS & NS & - & - & - & - & - \\
\hline
\end{tabular}

\footnotetext{
${ }^{1)}$ Abbreviations are the same as in Table 4.

${ }^{2}$ TP, total polyphenol; TF, total flavonoids; Total, sum of the 6, 8, 10 gingerol and 6, 8, 10 shogaol; 6-G, 6-gingerol; 8-G, 8-gingerol; 10-G, 10-gingerol; 6-S, 6-shogaol; 8-S, 8-shogaol; 10-S, 10-shogaol.

${ }^{3)}$ All values are mean $\pm \mathrm{SD}(\mathrm{n}=3)$.

${ }^{4) a-c}$ Means with different small letters in the same column (Stirring $2 \mathrm{~h}$, Sonication $0.5 \mathrm{~h}$, and Reflux $2 \mathrm{~h}$ ) differ significantly by Duncan's multiple range test (p<0.05).

${ }^{5) A-C}$ Means with different capital letters in the same column (Reflux $0.5,1$, and $2 \mathrm{~h}$ ) differ significantly by Duncan's multiple range test $(\mathrm{p}<0.05$ ).

6), $\mathrm{p}<0.05 ;{ }^{* *}, \mathrm{p}<0.01 ;{ }^{* * *}, \mathrm{p}<0.001$; NS, not significant.
} 
류냉각법이 각각 $6.50 \%, 3.21 \%$ 로 유의적( $\mathrm{p}<0.001)$ 으로 가 장 높게 나타났으며, 특히 교반법에 비하여 4.4배, 3.8 배 정도 차이가 나타났다. Jiajin 등(24)은 바이오에탄올로 가압 추출한 생강 연구에서 지표성분의 총합은 초음파 추출 $(1$ $\mathrm{g} / 50 \mathrm{~mL}, 25-30^{\circ} \mathrm{C}, 60$ 분 $)$ 이 $1.55 \%$, 환류냉각추출 $(1 \mathrm{~g} / 120$ $\mathrm{mL}, 85^{\circ} \mathrm{C}, 8$ 시간)이 $1.96 \%$ 로 보고하여 본 연구 결과보다는 3.3배 정도 낮게 나타났다. 또한, Jeong 등(25)은 약용식물의 항산화 및 항당뇨 활성 연구에서 당귀, 상엽, 총목피, 홍삼 열수 추출액의 TP 함량은 에탄올 $80 \%$ 추출액 보다 1.2-1.5 배 높았으며, 백복령과 상백피는 에탄올 $80 \%$ 추출액이 열 수추출액 보다 1.3-2.0배 높았다고 보고하였다. 본 연구의 시료인 생강의 경우에서도 추출조건에 따라 활성 차이가 있을 것으로 판단되었다.

효소처리 단계인 Step II의 $\mathrm{TP}$ 와 $\mathrm{TF}$ 는 환류냉각법이 각각 $0.85 \%$ 및 $0.05 \%$ 로 유의적으로 가장 낮게 나타났다. 이는 주정처리 단계인 Step I에서 수소 결합된 폐놀계 화합물이 용매와 고온처리에 의해 대부분 용출되었음을 시사하는 것이며, 주정처리에도 불구하고 소량의 성분이 생강 내 세 포벽과 전분에 잔존하고 있음을 나타내는 것이다. Step II의 gingerol 및 shogaol의 총합과 6-gingerol(6-G)의 함량 역시 환류냉각법이 유의적( $\mathrm{p}<0.001)$ 으로 가장 낮게 나타났으며, 교반법이나 초음파법에 비해 기능성분이 효과적으로 용출 되는 것을 확인할 수 있었다. 이는 $\mathrm{TP}$ 와 $\mathrm{TF}$ 의 결과와 유사 하였다. Step II의 8-G, 10-G, 6-S, 8-S, 10-S 함량은 검출되지 않았는데 이는 주정 처리 단계에서 생강 내의 기능성분이 거의 대부분 용출된 것으로 판단되었다. 결과적으로 주정 처리 방법별 기능성분 변화에서는 수용화 특성 변화에서와 마찬가지로 $\mathrm{TP}, \mathrm{TF}$, gingerol 및 shogaol의 총합과 6-gingerol(6-G) 함량이 유의적으로 가장 높게 나타난 환류 냉각법을 최적의 방법으로 선정하였다.

환류냉각법의 처리 시간에 따른 Step I의 TP는 2시간
처리구가 $4.75 \%, 1$ 시간 $4.26 \%, 0.5$ 시간 $4.08 \%$ 순으로 나타 났으며, 처리 시간이 증가할수록 유의적으로 높게 나타났 다( $\mathrm{p}<0.001) . \mathrm{TF}$ 는 2 시간 처리구가 $1.38 \%$ 로 유의적으로 높 게 나타났다 $(\mathrm{p}<0.05)$. Gingerol 및 shogaol의 총합과 6-gingerol(6-G)의 함량 역시 2 시간 처리구가 $6.50 \%, 3.21 \%$ 로 유의적으로 높게 나타났다( $\mathrm{p}<0.05)$. 6-G과 $10-\mathrm{G}$ 에서는 유의적인 차이가 없었으나 8-G는 처리 시간이 증가할수록 증가하는 경향으로 나타났다 $(\mathrm{p}<0.001)$. 처리 시간에 따른 Step II의 TP는 0.83-0.85\% 정도로 유의적인 차이는 나타나 지 않았다. $\mathrm{TF}$ 는 2 시간 처리구가 $0.05 \%$ 로 유의적으로 가장 낮게 나타났다(p<0.05). 생강 추출시 주정처리를 효소처리 전 단계에서 진행하는 것이 gingerol을 비롯하여 폴리페놀, 플라보노이드 등의 기능성분 추출에 더 효과적임이 확인되 었다. 결과적으로 생강의 주정처리는 환류냉각법으로 2시 간 동안 처리하는 것이 다당류 등의 수용화 증대 및 기능성 분 추출에 가장 효과적인 것으로 확인되었다.

\section{생강 처리 용량별 비교}

생강 처리 용량별 수용화 특성과 기능성분 변화는 Table 6, 7 과 같다. 주정처리 단계인 Step I에서 WSI는 8.51-9.47\% 의 범위로 처리 용량에 따른 유의적인 차이는 나타나지 않았다. TS는 $1.95-2.15 \%, \mathrm{RS}$ 는 $1.30-1.73 \%$ 의 범위로 유의 적인 차이가 나타났다.

효소처리 단계인 Step II의 WSI는 49.91-53.38\%, WAI는 1.84-6.81 g/mL로 처리 용량에 따른 유의적인 차이는 나타 나지 않았다. TS는 30.69-38.17\%의 범위로 $7.4-7.5 \%$ 의 편차 를 나타냈고, $\mathrm{RS}$ 는 $8.02-13.89 \%$ 의 범위로 $1.1-5.9 \%$ 의 편차 를 나타내었다. Lab-scale과 pilot scale에서 연구된 범위의 처리 용량에 대한 차이가 다소 나타났는데, 이는 추출 탱크 의 크기에 따라 효소처리 등의 최적 반응 시점에 도달하는 시간 등의 차이에 의한 것으로 판단되었다(26). 그리고

Table 6. Water solubility and composition of ginger extracts using different extraction volume

\begin{tabular}{|c|c|c|c|c|c|}
\hline Treatment & Working volume (L) & $\left.{ }^{2}\right)$ WSI (\%) & WAI $(\mathrm{g} / \mathrm{mL})$ & TS (\%) & RS (\%) \\
\hline \multirow{4}{*}{${ }^{1)}$ Step I } & 0.1 & 3) $9.47 \pm 0.59$ & - & $2.15 \pm 0.02^{\mathrm{a} 4)}$ & $1.63 \pm 0.00^{b}$ \\
\hline & 1 & $8.51 \pm 0.27$ & - & $1.95 \pm 0.03^{\mathrm{b}}$ & $1.73 \pm 0.02^{\mathrm{a}}$ \\
\hline & 35 & $8.84 \pm 0.95$ & - & $2.11 \pm 0.04^{\mathrm{a}}$ & $1.30 \pm 0.00^{\mathrm{c}}$ \\
\hline & F-value & $\mathrm{NS}^{5)}$ & - & $32.45^{* *}$ & $859.79^{* * *}$ \\
\hline \multirow{4}{*}{ Step II } & 0.1 & $49.91 \pm 4.81$ & 1.84 & $30.69 \pm 2.85^{\mathrm{b}}$ & $8.02 \pm 0.82^{\mathrm{c}}$ \\
\hline & 1 & $53.38 \pm 1.32$ & 5.03 & $38.17 \pm 2.29^{\mathrm{a}}$ & $9.12 \pm 0.18^{b}$ \\
\hline & 35 & $51.60 \pm 1.30$ & 6.81 & $30.79 \pm 0.44^{b}$ & $13.89 \pm 0.07^{\mathrm{a}}$ \\
\hline & F-value & NS & NS & $12.20^{* *}$ & $123.34^{* * *}$ \\
\hline
\end{tabular}

${ }^{1)}$ Step I, reflux treatment (ethanol extraction, $83^{\circ} \mathrm{C}, 2 \mathrm{~h}$ ); Step II, enzyme treatment (water bath shaking, non-adjusted pH, water extraction, pectinex ultra SP-L $(1 \%$ enzyme on substrate $5 \mathrm{~g}), 50^{\circ} \mathrm{C}, 2 \mathrm{~h}$ and termamyl $120 \mathrm{~L}(1 \%$ enzyme on substrate $5 \mathrm{~g}) 100^{\circ} \mathrm{C}, 1 \mathrm{~h}$ ).

${ }^{2)}$ WSI, water solubility index; WAI, water absorption index; TS, total sugar; RS, reducing sugar.

${ }^{3)}$ All values are mean $\pm \mathrm{SD}(\mathrm{n}=3)$.

${ }_{5)^{* *}}^{* 4-c}$ Means with different small letters in the same column differ significantly by Duncan's multiple range test $(\mathrm{p}<0.05)$.

5)**,$p<0.01 ;{ }^{* * *}, p<0.001$; NS, not significant. 
Table 7. Functional component content of ginger extracts using different extraction volume

\begin{tabular}{|c|c|c|c|c|c|c|c|c|c|c|}
\hline Treatment & Working volume (L) & ${ }^{21)} \mathrm{TP}(\%)$ & TF $(\%)$ & Total (\%) & 6-G (\%) & 8-G (\%) & 10-G (\%) & 6-S (\%) & 8-S (\%) & $10-\mathrm{S}(\%)$ \\
\hline \multirow{4}{*}{${ }^{1)}$ Step I } & 0.1 & 3) $4.66 \pm 0.09^{\mathrm{a4})}$ & $0.57 \pm 0.10$ & $5.30 \pm 0.49^{b}$ & $1.74 \pm 0.02^{\mathrm{b}}$ & $0.89 \pm 0.09^{b}$ & $1.34 \pm 0.12^{\mathrm{b}}$ & $0.73 \pm 0.10$ & $0.43 \pm 0.10$ & $0.17 \pm 0.06$ \\
\hline & 1 & $4.57 \pm 0.04^{\mathrm{a}}$ & $0.64 \pm 0.06$ & $6.30 \pm 0.16^{\mathrm{a}}$ & $2.37 \pm 0.02^{\mathrm{a}}$ & $1.05 \pm 0.04^{\mathrm{a}}$ & $1.60 \pm 0.04^{\mathrm{a}}$ & $0.78 \pm 0.05$ & $0.36 \pm 0.02$ & $0.14 \pm 0.01$ \\
\hline & 35 & $3.41 \pm 0.01^{\mathrm{b}}$ & $0.49 \pm 0.04$ & $5.49 \pm 0.04^{b}$ & $1.73 \pm 0.00^{b}$ & $0.91 \pm 0.02^{\mathrm{b}}$ & $1.47 \pm 0.00^{\mathrm{ab}}$ & $0.72 \pm 0.01$ & $0.44 \pm 0.02$ & $0.21 \pm 0.02$ \\
\hline & F-value & $418.35^{* * * 5)}$ & NS & $9.61^{*}$ & $1,395.81^{* * *}$ & $7.13^{*}$ & $8.45^{*}$ & NS & NS & NS \\
\hline \multirow{4}{*}{ Step II } & 0.1 & $0.73 \pm 0.08^{b}$ & $0.07 \pm 0.01^{b}$ & $0.03 \pm 0.00^{c}$ & $0.03 \pm 0.00^{c}$ & $0.00 \pm 0.00$ & $0.00 \pm 0.00^{c}$ & $0.00 \pm 0.00^{b}$ & - & - \\
\hline & 1 & $0.75 \pm 0.06^{b}$ & $0.10 \pm 0.02^{\mathrm{a}}$ & $0.10 \pm 0.00^{b}$ & $0.09 \pm 0.00^{b}$ & $0.00 \pm 0.00$ & $0.01 \pm 0.00^{\mathrm{b}}$ & $0.00 \pm 0.00^{b}$ & - & $0.00 \pm 0.00$ \\
\hline & 35 & $1.04 \pm 0.02^{\mathrm{a}}$ & $0.05 \pm 0.01^{\mathrm{b}}$ & $0.89 \pm 0.01^{\mathrm{a}}$ & $0.62 \pm 0.00^{\mathrm{a}}$ & $0.13 \pm 0.00$ & $0.11 \pm 0.00^{\mathrm{a}}$ & $0.02 \pm 0.00^{\mathrm{a}}$ & - & $0.01 \pm 0.00$ \\
\hline & F-value & $25.01^{* *}$ & $15.91^{* *}$ & $20,436.33^{* * *}$ & $28,081.00^{* * *}$ & NS & $1,027.00^{* * *}$ & $25.00^{* *}$ & - & NS \\
\hline
\end{tabular}

${ }^{1)}$ Abbreviations are the same as in Table 6

${ }^{2}$ TP, total polyphenol; TF, total flavonoids; Total, sum of the 6, 8, 10 gingerol and 6, 8, 10 shogaol; 6-G, 6-gingerol; 8-G, 8-gingerol; 10-G, 10-gingerol; 6-S, 6-shogaol; 8-S, 8-shogaol; 10-S, 10-shogaol.

${ }^{3)}$ All values are mean $\pm \mathrm{SD}(\mathrm{n}=3)$

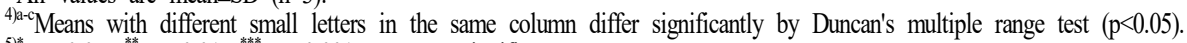

$\left.{ }^{5}\right)^{*}, \mathrm{p}<0.05 ;{ }^{* *}, \mathrm{p}<0.01 ;{ }^{* * *}, \mathrm{p}<0.001$; NS, not significant.

lab-scale에서의 사용하는 진탕기 또는 교반기와 pilot scale 에서 사용하는 대용량 반응조에 장착된 임펠라 팁의 표면적 또는 회전력 등에 의한 물리적인 힘의 차이에 의한 것으로 예상되었다(27).

Step I에서 TP 함량은 3.41-4.66\%의 범위로 처리 용량에 따라 유의적인 차이를 나타내었고, TF 함량은 $0.49-0.64 \%$ 의 범위로 유의적인 차이가 나타나지 않았다. Gingerol과 shogaol의 총합은 $5.30-6.30 \%$ 의 범위를 나타내었으며, gingerol에 비해 shogaol은 유의적인 차이가 없었다. Nagendra 등(28)은 생강의 항산화 성분 추출을 위해 효소 전처리 $(0.5 \%, \mathrm{~mL} / \mathrm{w})$ 후 용매별 추출의 차이를 비교한 연구 에서, cellulose 처리 후 에탄올 추출(3.75\%)이 효과적이었 다고 보고하였으나 본 실험 결과보다 1.5 배 정도 낮게 나타 났다. 이와 같은 결과로 주정 및 효소 복합처리는 처리 순서 에도 영향을 받으며, 주정처리 후 효소처리를 진행하는 것 이 더 효과적임을 확인할 수 있었다.

Step II에서 TP는 $0.73-1.04 \%$, TF는 $0.05-0.10 \%$ 의 범위로 나타났다. Gingerol과 shogaol의 총합은 $0.03-0.89 \%$ 로 0.1-0.9\%의 편차를 나타내었으며, gingerol과 shogaol 함량 은 처리 용량이 증가할수록 지표성분 총합과 6-G, 10-G, 6-S의 함량이 유의적으로 증가하였다 $(\mathrm{p}<0.01, \mathrm{p}<0.001)$.

처리 용량별 수용화 특성 및 기능성분 함량에 대한 가변 율은 Step I과 Step II의 결과를 합산 후, 처리 용량별의 평균치를 제로 값으로 설정하여 비교하였다(Fig. 2). 처리 용량에 따라 각 항목별로 $\pm 6-7 \%$ 정도의 가변율을 나타났으 며, 이와 같은 결과로 생강 대량 추출 적용 가능성을 확인하 였다.

결과적으로, 효소처리 전 주정 처리 단계를 통하여 생강 의 기능성분 추출을 극대화하고, 그 다음 단계인 효소처리 과정을 통하여 전분, 섬유소, 펙틴 등의 다당류의 분해 또는 수용화를 증진시킬 수 있음을 확인하였다. 그리고 처리 용량 별 확인 실험을 통하여 대량생산의 가능성까지 검증하였다.

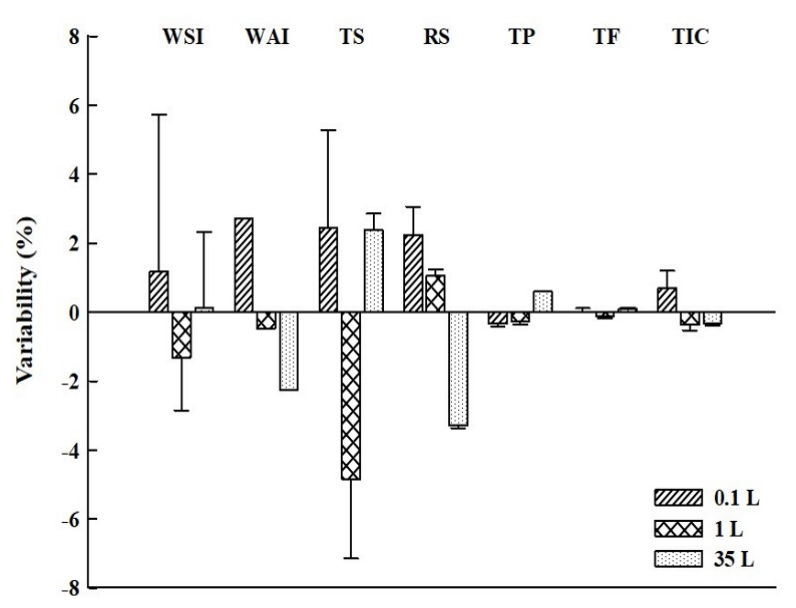

Fig. 2. Variability depending on different extraction scales of ginger extract by ethanol and enzyme treatment.

$\bigotimes 0.1 \mathrm{~L}$, laboratory scale; $\otimes 1 \mathrm{~L}$, laboratory scale; $\square 35 \mathrm{~L}$, pilot-scale WSI, water solubility index; WAI, water absorption index; TS, total sugar; RS, reducing sugar; TP, total polyphenol; TF, total flavonoids; TIC, total indicate components; sum of $6,8,10$-gingerol and $6,8,10$-shogaol.

\section{요 약}

본 연구는 생강의 다당류 수용화 특성을 증진시킬 수 있는 효소처리 조건과 기능성분의 추출 수율을 극대화할 수 있는 주정처리 최적 조건을 선정하고자 하였으며, 추출 용량별 비교 실험을 통하여 대량 생산의 적용성을 검토하였 다. 효소처리 방법별로 비교한 결과, 효소처리 최적 $\mathrm{pH}$ 로 조정한 단일효소처리구 $\mathrm{A}$ 와 조정하지 않은 $\mathrm{B}$ 의 수분용해 지수(WSI)는 각각 $58.56 \%, 53.44 \%$ 로 대조구(CON) $15.35 \%$ 에 비하여 3.5-3.8배 정도 유의적으로 높게 나타났으며 ( $\mathrm{p}<0.001)$, 단일효소처리구 $\mathrm{B}$ 는 $\mathrm{A}$ 에 비하여 $5.1 \%$ 정도 낮게 나타났다. 주정처리 방법 및 시간별로 비교한 결과, 총 폴리 
페놀(TP)은 환류냉각법 $4.75 \%$, 초음파법 $3.62 \%$, 교반법 $1.31 \%$ 순으로 나타났으며, 환류냉각법이 교반법에 비해 3.6 배 높게 나타났다( $\mathrm{p}<0.001)$. 환류냉각법의 총 플라보노 이드(TF)와 지표성분의 총합은 각각 $1.38 \%, 6.50 \%$ 로 교반 추출법 비해 2.3배, 4.4 배 유의적으로 높게 나타났다 $(\mathrm{p}<0.001)$. 주정처리 단계인 Step I에서 환류냉각법의 처리 시간별 $\mathrm{TP}$ 와 $\mathrm{TF}$, 지표성분 함량은 처리 시간이 증가할수록 유의적으로 높아졌다. 생강 처리 용량별 가변율은 각 항목 별로 $\pm 6-7 \%$ 내의 범위로 나타나 생강 대량 추출 적용 가능 성을 확인하였다. 결과적으로 단일효소처리구 $\mathrm{B}$ 는 $\mathrm{A}$ 에 비 해 수용화 특성은 $5.1 \%$, 기능성분은 $0.3-0.9 \%$ 정도 감소하 는 경향이 나타났으나, 산업적 대량 추출에서는 $\mathrm{pH}$ 조정 단계는 생략하고 진행하는 것이 생산 효율성을 극대화할 수 있는 방법이라고 판단되었다. 그리고 효소처리 전 주정 처리를 통하여 생강의 기능성분 추출을 극대화할 수 있음을 확인하였으며, 주정처리는 환류냉각법으로 2시간 동안 처 리하는 것이 가장 효과적인 것으로 확인되었다. 이러한 결 과를 통해 생강의 부가가치 증진 및 소비 확대를 위한 기능 성 소재 개발과 관련 농산 업체의 현장 적용을 위한 기초 자료로 활용될 수 있을 것이라 생각된다.

\section{감사의 글}

본 성과물은 농촌진흥청 연구사업(PJ01255401)의 지원 에 의하여 이루어진 것이며, 깊은 감사드립니다.

\section{References}

1. Tahereh A, Naheed A (2018) The effect of ginger (Zingiber officinale) as an ancient medicinal plant on improving blood lipids. J Herb Med, 12, 11-15

2. Krishnapura S (2017) Ginger rhizomes (Zingiber officinale): A spice with multiple health beneficial potentials. PharmaNutrition, 5, 18-28

3. Baokang H, Guowei W, Zhiyong C, Luping Q (2012) Effect of Oven Drying, Microwave Drying, and Silica Gel Drying Methods on the Volatile Components of Ginger (Zingiber officinale Roscoe) by HS-SPMEGC-MS. Drying Technol, 30, 248-255

4. Lee HO, Lee YJ, Kim JY, Kwon KH, Kim BS (2017) Extension of ginger shelf-life using a forced evaporation humidifier. Hortic sci technol, 35, 555-567

5. Park KM, Ku KH, Koo MS (2018) Antifungal activity of plant extracts against Fusarium oxysporum isolated from spoilage ginger. Korean J Food Preserv, 25, 173-180
6. Lee HO, Kim BS (2016) Storage management technology of ginger. Magazine SAREK, 45, 44-51

7. Ding SH, An KJ, Zhao CP, Li Y, Guo YH, Wang ZF (2012) Effect of drying methods on volatiles of Chinese ginger (Zingiber officinale Roscoe). Food Bioprod Process, 90, 515-524

8. Kejing A, Dandan Z, Zhengfu W, Jijun W, Yujuan X, Gengsheng X (2016) Comparison of different drying methods on Chinese ginger (Zingiber officinale Roscoe): changes in volatiles, chemical profile, antioxidant properties, and microstructure. Food Chem, 197, 1292-1300

9. Kim KT (2011) Development of value-added ginger products for industrial application and export. Final report of MAFRA, MAFRA 11-1541000-001242-01

10. Kate AE, Sutar PP (2018) Development and optimization of novel infrared dry peeling method for ginger (Zingiber officinale Roscoe) rhizome. Innovative Food Sci Emerging Technol, 48, 111-121

11. Nam DG, Kim MN, Im PR, Kim SB, Choe JS, Choi AJ (2018) Solubilization of polysaccharide and functional components by high-pressure enzyme treatment from ginger (Zingiber officinale Rosc.). Food Eng Prog, 22, 173-185

12. Anderson RA, Conway HF, Pfeifer VF, Griffin J (1969) Gelatinization of corn grits by roll-and extrusion-cooking. Cereal Sci Today, 14, 4-7

13. Dubois M, Gilles KA, Hamilton JK, Rebers PT, Smith F (1956) Colorimetric method for determination of sugars and related substances. Anal chem, 28, 350-356

14. Miller GL (1959) Use of dinitrosalicylic acid reagent for determination of reducing sugar. Anal chem, 31, 426-428

15. Swain T, Hillis WE (1959) The phenolic constituents of Prunus domestica I-The quantitative analysis of phenolic constituents. J Sci Food Agric, 10, 63-68

16. Zhishen J, Mengcheng T, Jianming W (1999) The determination of flavonoid contents in mulberry and their scavenging effects on superoxide radicals. Food chem, 64, 555-559

17. Yakup A, Aziz T (2007) Immobilization of Pectinex Ultra SP-L to produce galactooligosaccharides. J Mol Catal B:Enzym, 45, 73-77

18. Deniz T, Belma IY, Ahmet RO (1998) Immobilization of a thermostable a-amylase, Termamyl ${ }^{\circledR}$, onto nitrocellulose membrane by Cibacron Blue F3GA dye binding. Biochem Eng J, 2, 179-186 
19. Kim JW, Youn KS (2014) Polyphenolic compounds, physiological activities, and digestive enzyme inhibitory effect of Aster scaber thunb. extracts according to different extraction processes. J Korean Soc Food Sci Nutr, 43, 1701-1708

20. Kim JH, Lee S (2016) Antioxidative and antimicrobial activities of Oenothera biennis extracted by different methods. Korean J Food Preserv, 23, 233-238

21. Won BY, Shin KY, Ha HJ, Yun YS, Kim YR, Lee HG (2015) Changes in nutritional composition of dropwort (Oenanthe javanica) ethanol extracts. J Korean Soc Food Sci Nutr, 44, 882-887

22. Kim YS, Kim R, Moon JH, Ji JR, Choi HD, Park YK (2009) Optimization of extraction conditions of polyphenolic compounds from apple pomace by response surface methodology. Korean J Food Sci Technol, 41, 245-250

23. Jung YS, Park SJ, Park JH, Jhee KH, Lee IS, Yang SA (2012) Effects of ethanol extracts from Zingiber officinale Rosc., Curcuma longa L., and Curcuma aromatica Salisb. on acetylcholinesterase and antioxidant activities as well as GABA contents. J Korean Soc Food Sci Nutr, 41, $1395-1401$
24. Jiajin H, Zheng G, Marianne G, Kasper K, Langtao X, Xuebing X (2011) Pressurized liquid extraction of ginger (Zingiber officinale Roscoe) with bioethanol: An efficient and sustainable approach. J Chromatogr A, 1218, 5765-5773

25. Jeong HJ, Lee SG, Lee EJ, Park WD, Kim JB, Kim HJ (2010) Antioxidant activity and antihyperglycemic activity of medicinal herbal extracts according to extraction methods. Korean J Food Sci Technol, 42, 571-577

26. Tufvesson P, Fu W, Jensen JS, Woodley JM (2010) Process considerations for the scale-up and implementation of biocatalysis. Food Bioprod Process, 88, 3-11

27. Marques MPC, Cabral JMS, Fernades P (2010) Bioprocess scale-up: quest for the parameters to be used as criterion to move from microreactors to lab-scale. J Chem Technol Biotechnol, 85, 1184-1198

28. Nagendra chari KL, Manasa D, Srinivas P, Sowbhagya HB (2013) Enzyme-assisted extraction of bioactive compounds from ginger (Zingiber officinale Roscoe). Food Chem, 139, 509-514 